\title{
NURSING TEAM KNOWLEDGE ABOUT PRESSURE INJURIES
}

\author{
Jaqueline Aparecida dos Santos Sokem 1,* (D), Elaine Aparecida Mye Takamatu Watanabe² (D), \\ Adriano Menis Ferreira ${ }^{3}$ (D), Lillian Dias Castilho Siqueira ${ }^{4}$ (D), Manuela de Mendonça \\ Figueirêdo Coelho ${ }^{5}$ (D), Fabiana Perez Rodrigues Bergamaschi²
}

\begin{abstract}
Objective: to assess the level of knowledge of the nursing staff of the medical clinic of a university hospital about pressure injuries. Method: descriptive-exploratory study, approved by the Research Ethics Committee. Data were collected through a validated questionnaire. Fifty individuals participated, 35 nursing technicians and 15 nurses. Results: nursing technicians had an average of $83.5 \%$ and nurses had an average of $89.9 \%$. A regression model was carried out to verify variables that influence the level of knowledge, and it was identified that having more than 5 years in the profession increases 1.61 times the chance that the professional has adequate knowledge. Conclusion: a weakness in knowledge about pressure injuries was identified. In view of the costs involved in the treatment and complications arising from these injuries, health institutions must implement educational actions about this condition.
\end{abstract}

DESCRIPTORS: Pressure injury. Nursing care. Patient safety. Stomatherapy.

\section{CONHECIMENTO DA EQUIPE DE ENFERMAGEM SOBRE LESÃO POR PRESSÃO}

\section{RESUMO}

\begin{abstract}
Objetivo: avaliar o nível de conhecimentos da equipe de enfermagem da clínica médica de um hospital universitário sobre lesão por pressão. Método: estudo descritivo-exploratório, aprovado por Comitê de Ética em Pesquisa. Os dados foram coletados através de questionário validado. Participaram 50 indivíduos, sendo 35 técnicos de enfermagem e 15 enfermeiros. Resultados: os técnicos em enfermagem obtiveram média de 83,5\% e os enfermeiros obtiveram média de 89,9\%. Realizou-se um modelo de regressão para verificar variáveis que influenciam no nível de conhecimento, sendo identificado que possuir mais de 5 anos na profissão aumenta 1,61 vezes a chance de o profissional apresentar um conhecimento adequado. Conclusão: foi identificada uma fragilidade no conhecimento sobre lesão por pressão. Tendo em vista os custos envolvidos no tratamento e as complicações advindas dessas lesões, as instituições de saúde devem implementar ações educativas sobre esse agravo.
\end{abstract}

DESCRITORES: Lesão por pressão. Cuidados de enfermagem. Segurança do paciente. Estomaterapia.

1. Universidade Federal da Grande Dourados - Hospital Universitário - Unidade de Clínica Médica - Dourados (MS), Brazil.

2. Universidade Estadual do Mato Grosso do Sul - Centro de Ciências Agrárias, Biológicas e da Saúde - Departamento de Enfermagem - Dourados (MS), Brazil.

3. Universidade Federal do Mato Grosso do Sul - Centro de Ciências Biológicas e da Saúde - Departamento de Enfermagem Três Lagoas (MS), Brazil.

4. Universidade Federal da Grande Dourados - Hospital Universitário - Setor de Gestão da Pesquisa e Inovação Tecnológica Dourados (MS), Brazil.

5. Universidade Federal do Ceará - Centro de Ciências da Saúde - Departamento de Enfermagem - Fortaleza (CE), Brazil.

*Correspondence author: jaqueline_skm@hotmail.com

Section Editor: Juliano Teixeira Moraes

Received: Sept. 03, 2021 | Accepted: Nov. 01, 2021

How to cite: Sokem JAS; Watanabe EAMT; Ferreira AM; Siqueira LDC; Coelho MMF; Bergamaschi FPR. Nursing team knowledge about pressure injuries. ESTIMA, Braz. J. Enterostomal Ther., 2021, 19: e2521. https://doi.org/10.30886/estima.v19.1129_IN 


\section{CONOCIMIENTOS DEL EQUIPO DE ENFERMERÍA SOBRE LA LESIÓN \\ POR PRESIÓN}

\section{RESUMEN}

Objetivo: evaluar el nivel de conocimientos del equipo de enfermería de clínica médica de un hospital universitario sobre lesión por presión. Método: estudio descriptivo/exploratorio, aprobado por Comité de Ética en Investigación. Los datos fueron recolectados por medio de un cuestionario validado. Participaron 50 individuos, siendo 35 técnicos de enfermería y 15 enfermeros. Resultados: los técnicos en enfermería obtuvieron un promedio del 83,5 \% y los enfermeros un promedio del 89,9\%. Se realizó un modelo de regresión para verificar variables que influyen en el nivel de conocimiento, identificándose que el contar con más de 5 años en la profesión aumenta 1,61 veces la probabilidad que el profesional presente un conocimiento adecuado. Conclusión: fue identificada una fragilidad en el conocimiento sobre lesión por presión. Teniendo en cuenta los costos involucrados en el tratamiento y las complicaciones derivadas de esas lesiones, las instituciones de salud deben implementar acciones educativas sobre esa afección.

DESCRIPTORES: Lesión por presión. Cuidados de enfermería. Seguridad del paciente. Estomaterapia.

\section{INTRODUCTION}

In recent years, hospital care has become more complex due to growing technological innovation, the countless activities performed by professionals, in addition to the presence of interruptions in patient care. From this perspective, unsafe care results in preventable morbidity and mortality, with individuals more vulnerable to complications such as pressure injury $(\mathrm{PI})^{1,2}$.

PI is evaluated as a negative indicator of the quality of health care, being defined as localized damage to the skin and/ or underlying soft tissue over a bony prominence. PI may also be related to the use of a medical device or other artifact. It is understood as an adverse event and represents an important care challenge, as it generates physical and psychological suffering for patients and families, in addition to high financial costs for institutions ${ }^{3,4}$.

A study conducted in a university hospital in Minas Gerais identified a frequency of PI of 29\% in the medical clinic unit, $16 \%$ in the surgical clinic and $53.8 \%$ in the observation of the emergency room. In the international scenario, a research aimed at analyzing the prevalence and characteristics of PI related to the use of medical devices in patients from Canadian and North American institutions identified that the overall prevalence was $7.2 \%$, and the prevalence acquired in institutions was $3 \cdot 1 \%^{5,6}$.

The recommendations for the prevention and treatment of chronic wounds involve the systematic assessment of the patient and his wound, the control of causal and associated factors and the preparation of the wound bed, elements that require constant updating by nurses ${ }^{7}$.

In this context, researchers developed international guidelines related to the prevention and treatment of PI, considering, among the guidelines and conducts on this injury, recommendations for the implementation of public policies, education of professionals and research on the subject. However, despite these guidelines, studies point to deficiencies in the knowledge of professionals, in addition to high rates of incidence and prevalence of PI in health services and households ${ }^{8-10}$.

Among the various professionals that make up the multidisciplinary team, the nursing team remains in contact with patients in health institutions for a longer time. In clinical settings, they play a fundamental role in taking preventive actions. Hence the importance of maintaining adequate levels of knowledge and assertive attitudes on the part of these professionals. The use of care practices based on evidence-based nursing favors the reduction of hospital stay and the reduction of adverse events ${ }^{11,12}$.

Given the above and considering the constant need to diagnose the level of knowledge of health professionals about $\mathrm{PI}$, as well as the scarcity of publications on this topic in the Midwest region of Brazil, the objective of the present article is justified: to evaluate the level of knowledge about PI, of the nursing staff of the medical clinic of a university hospital. 


\section{METHOD}

Descriptive and exploratory study, with a quantitative approach regarding the treatment of data, conducted from August to September 2017, carried out in the Hospital Universitário da Universidade Federal da Grande Dourados/Empresa Brasileira de Serviços Hospitalares (HU-UFGD/EBSERH), with the nursing staff of the medical clinic. The institution where the research was carried out is of medium complexity and is located in the state of Mato Grosso do Sul, being a reference for 35 municipalities, including the indigenous and border populations.

Ethical aspects were respected in line with resolution no 466/2012. The project was approved by the Research Ethics Committee of the Universidade Estadual de Mato Grosso do Sul,under opinion no. 2,197,369 and CAAE 70593017.8.0000.8030. All participants signed the Informed Consent Form and kept a copy in their possession.

The total staff of nursing professionals in the unit was 57 nursing technicians and 15 nurses ( $n=72)$. All professionals present during the data collection period were invited to participate. A non-probabilistic convenience sample was chosen due to the characteristics of the sector in which PI is prevalent. The inclusion criteria were: to work directly in the care of patients at the unit and to voluntarily accept to participate in the study. Exclusion criteria were: absence of the server due to vacation, sick leave or time off.

For the collection of information, first, an instrument developed by the authors of this study was used, in order to collect the sociodemographic data of the professionals. As for data collection regarding the level of knowledge, the Pieper Test was used. This test presents 41 statements with items related to the prevention, evaluation and classification of $\mathrm{PI}^{13}$. This test was translated and validated in a study carried out in Brazi ${ }^{14}$. At the time of data collection (2017), this was the instrument available in Brazil to assess PI knowledge, however, in 2018, another instrument for this purpose was translated, cross-culturally adapted and validated in Brazilian Portuguese 4 .

For the present research, the questionnaire underwent adaptations due to the updating of the literature on the subject, which will be described below: change from the term pressure ulcer to pressure injury; modification in item 8 , removing the indication for use of cornstarch and adding the polyurethane foam cover to prevent friction, and change in item 26, in which the term Intensive Care Unit was modified for the sector, since the application of the instrument took place in a medical clinic unit ${ }^{8}$. The changes did not go through a validation process, however, the use of the instrument and the modifications were authorized by the author.

The instrument was applied individually, during the work shift, and returned in an envelope to the researcher, without identification, in order to ensure the anonymity of the participants.

Data was entered and double-entered. Subsequently, statistical analysis was performed using the Statistical Package for Social Science (SPSS) program, version 22.0. Descriptive statistical analysis and statistical tests were performed to compare possible variables. To verify possible differences between the correct answers scores between the professional categories, the Student $t$ test and the Mann-Whitney test were applied. When considering the adequate knowledge represented by the percentage of correct answers of $90 \%$ of the items, the level of knowledge of professionals was dichotomized into adequate (average greater than or equal to 36.9) and not adequate (average less than 36.9)14.

A binary logistic regression (enter method) was performed to identify whether the variables working time (greater than or equal to 5 years), having previous training on PI and Incontinence Associated Dermatitis (IAD) (yes or no) and position (nurse or technical) would be predictors for the outcome of adequate knowledge. A significance level of $5 \%$ was adopted.

\section{RESULTS}

The study consisted of 50 nursing professionals. Of these, 35 were nursing technicians and 15 nurses. The sample was characterized by predominant age ranging from 30 to 39 years old (46\%), followed by 20 to 29 years old (22\%); female (56\%) and professional experience between 5 and 9 years and 15 and 19 years (both 26\%). Regarding the level of education of professionals, $(62 \%)$ had an undergraduate degree and (46\%) had a specialization. 
Considering the average of overall correct answers for the 41 questions, the nursing technicians had an average of (83.5\%) and the nurses had an average of (89.9\%). Items about the PI evaluation and classification are described in Table 1.

Table 1. Frequency of correct answers by participants in the test, according to the items on evaluation and classification of pressure injuries. Dourados (MS), Brasil - 2017.

\begin{tabular}{|c|c|c|c|}
\hline Issues evaluated & $\begin{array}{c}\text { Nursing } \\
\text { technician } \\
\mathrm{N}(\%)\end{array}$ & $\begin{array}{l}\text { Nurse } \\
\mathrm{N}(\%)\end{array}$ & $\begin{array}{l}\text { Total } \\
\mathrm{N}(\%)\end{array}$ \\
\hline 1 - PI stage I is defined as non-whitening erythema $(T)$ & $35(100.0)$ & $14(93.3)$ & $48(96.0)$ \\
\hline 6 - A stage III PI is a partial loss of skin involving the epidermis. (F) & $32(91.4)$ & $15(100.0)$ & $47(94.0)$ \\
\hline $\begin{array}{l}9 \text {-Stage IV PIs present with a total loss of skin with intense tissue destruction } \\
\text { and necrosis or damage to muscles, bones or supporting structures (T) }\end{array}$ & $34(97.1)$ & $15(100.0)$ & $49(98.0)$ \\
\hline 20 - PI in stage II show a loss of full-thickness skin(F) & $17(48.6)$ & $10(66.6)$ & $27(54.0)$ \\
\hline 31 - PI are sterile wounds (F) & $31(88.6)$ & $14(93.3)$ & $45(90.0)$ \\
\hline 32 - An PI scar may damage faster than intact skin (T) & $33(94.3)$ & $15(100.0)$ & $48(96.0)$ \\
\hline 33 - A blister on the heel should not be a cause for concern. (F) & $34(97.1)$ & $15(100.0)$ & $49(98.0)$ \\
\hline $\begin{array}{l}38 \text { - Stage II PI can be extremely painful due to the exposure of nerve } \\
\text { endings }(T)\end{array}$ & $21(60.0)$ & $12(80.0)$ & $33(66.0)$ \\
\hline
\end{tabular}

$\mathrm{Pl}=$ Pressure Injury; $\mathrm{T}=$ True; F=False; $\mathrm{N}$ = Frequency.

The highest rate of correct answers in the PI assessment and classification category was obtained by nurses in items $6,9,32$ and 33, with $100 \%$ accuracy. The same professionals had a lower rate of correct answers in item 20 . In relation to technicians, they achieved a high rate of correct answers in items 1, 9 and 33; they also had a lower mean in item 20.

Considering the total number of respondents, there was a weakness in knowledge about classification of stage II PI (item 20) and in the question regarding the presence of pain in stage II PI (item 38). Items related to PI prevention are described in Table 2.

Table 2.Frequency of correct answers by participants in the test, according to the items on pressure injury prevention. Dourados (MS), Brasil - 2017.

\begin{tabular}{|c|c|c|c|}
\hline Issues evaluated & $\begin{array}{l}\text { Nursing } \\
\text { technician } \\
\mathrm{N}(\%)\end{array}$ & $\begin{array}{l}\text { Nurse } \\
\mathrm{N}(\%)\end{array}$ & $\begin{array}{l}\text { Total } \\
\mathrm{N}(\%)\end{array}$ \\
\hline $\begin{array}{l}2 \text { - The risk factors for the development of PI are: mobility; incontinence; } \\
\text { proper nutrition and altered level of consciousness }(T)\end{array}$ & $31(88.6)$ & $14(93.3)$ & $45(90.0)$ \\
\hline $\begin{array}{l}3 \text { - All individuals at risk for PI should have a systematic skin inspection at least } \\
\text { once a week (F) }\end{array}$ & $35(100.0)$ & $15(100.0)$ & $50(100.0)$ \\
\hline 4 - Hot water and soap can dry out the skin and increase the risk for PI (T) & $24(68.6)$ & $11(73.3)$ & $35(70.0)$ \\
\hline 5 - It is important to massage the bony prominences if they are hyperemics $(F)$ & $17(48.6)$ & $12(80.0)$ & $29(58.0)$ \\
\hline $\begin{array}{l}7 \text { - Every individual, upon hospital admission, must be evaluated for the risk of } \\
\text { developing PI (T) }\end{array}$ & $35(100.0)$ & $15(100.0)$ & $50(100.0)$ \\
\hline $\begin{array}{l}8 \text { - Creams, clear dressings (Tegaderm or Opsite type), polyurethane foam } \\
\text { dressings and/or hydrocolloids (Duoderm type) do not protect against the } \\
\text { effects of friction (F) }\end{array}$ & $28(80.0)$ & $15(100.0)$ & $43(86.0)$ \\
\hline $\begin{array}{l}10 \text { - A dietary intake adequate to the patient's protein and calorie needs must } \\
\text { be maintained during the illness. }(T)\end{array}$ & $35(100.0)$ & $15(100.0)$ & $50(100.0)$ \\
\hline 11 - People who are bedridden must be repositioned every 3 hours (F) & $28(80.0)$ & $15(100.0)$ & $43(86.0)$ \\
\hline
\end{tabular}


Table 2. Continuation...

\begin{tabular}{|c|c|c|c|}
\hline Issues evaluated & $\begin{array}{l}\text { Nursing } \\
\text { technician } \\
\text { N (\%) }\end{array}$ & $\begin{array}{l}\text { Nurse } \\
\mathrm{N}(\%)\end{array}$ & $\begin{array}{l}\text { Total } \\
\mathrm{N}(\%)\end{array}$ \\
\hline 12 - A scale with times to change position should be written for each patient & $32(91.4)$ & $13(86.7)$ & $45(90.0)$ \\
\hline 13 - Protectors such as water gloves relieve pressure on the heels $(F)$ & $12(34.3)$ & $11(73.3)$ & $23(46.0)$ \\
\hline 14 - Water wheels or ring-type pads help prevent PI (F) & $10(28.6)$ & $12(80.0)$ & $22(44.0)$ \\
\hline $\begin{array}{l}15 \text { - In the lateral position, the person should be at a 30-degree angle with } \\
\text { the bed }(T)\end{array}$ & $27(77.1)$ & $12(80.0)$ & $39(78.0)$ \\
\hline $\begin{array}{l}16 \text { - The head of the bed should be kept at a low degree of elevation (no } \\
\text { more than a } 30 \text { degree angle), consistent with clinical conditions and medical } \\
\text { recommendations. }(T)\end{array}$ & $15(42.8)$ & $07(46.7)$ & $22(44.0)$ \\
\hline $\begin{array}{l}17 \text { - A person who cannot move must be repositioned, while sitting in the chair, } \\
\text { every } 2 \text { hours (F) }\end{array}$ & $11(31.4)$ & $03(20.0)$ & $14(28.0)$ \\
\hline $\begin{array}{l}18 \text { - People with the ability to learn should be instructed to change their weight } \\
\text { every } 15 \text { minutes while sitting in the chair. }(T)\end{array}$ & $28(80.0)$ & $11(73.3)$ & $39(78.0)$ \\
\hline $\begin{array}{l}19 \text {-Persons who remain in the chair must use a cushion for protection in the } \\
\text { seat. }(T)\end{array}$ & $31(88.6)$ & $12(80.0)$ & $43(86.0)$ \\
\hline 21 - The skin must remain clean and dry $(\mathrm{T})$ & $35(100.0)$ & $15(100.0)$ & $50(100.0)$ \\
\hline $\begin{array}{l}22 \text { - Prevention measures need not be used to prevent further injuries when } \\
\text { the patient already has PI (F) }\end{array}$ & $29(82.9)$ & $15(100.0)$ & $44(88.0)$ \\
\hline 23 - Movable sheet or liners must be used to transfer or move patients (T) & $35(100.0)$ & $14(93.3)$ & $49(98.0)$ \\
\hline $\begin{array}{l}24 \text { - The mobilization and transfer of fully dependent patients must be done by } \\
\text { two or more people(T) }\end{array}$ & $34(97.1)$ & $15(100.0)$ & $49(98.0)$ \\
\hline $\begin{array}{l}25 \text { - Rehabilitation measures should be instituted if the patient's general } \\
\text { condition allows }(T)\end{array}$ & $33(94.3)$ & $12(80.0)$ & $45(90.0)$ \\
\hline $\begin{array}{l}26 \text { - Every patient admitted to the sector must undergo risk assessment for the } \\
\text { development of PI (T) }\end{array}$ & $33(94.3)$ & $15(100.0)$ & $48(96.0)$ \\
\hline $\begin{array}{l}27 \text { - Patients and family members should be advised about the causes and risk } \\
\text { factors for the development of PI (T) }\end{array}$ & $35(100.0)$ & $15(100.0)$ & $50(100.0)$ \\
\hline 28 - The bony prominences must be in direct contact with each other $(F)$ & $35(100.0)$ & $15(100.0)$ & $50(100.0)$ \\
\hline $\begin{array}{l}29 \text { - Every person assessed as at risk for developing PI should be placed on a } \\
\text { pressure-reducing mattress }(T)\end{array}$ & $29(82.9)$ & $12(80.0)$ & $41(82.0)$ \\
\hline 30 - Skin exposed to moisture is more easily damaged(T) & $34(97.1)$ & $15(100.0)$ & $49(98.0)$ \\
\hline 34 - A good way to reduce pressure on the heels is to raise them from the bed ( $T$ ) & $34(97.1)$ & $13(86.7)$ & $47(94.0)$ \\
\hline 35 - All care given to prevent or treat PI does not need to be documented. (F) & $32(91.4)$ & $15(100.0)$ & $47(94.0)$ \\
\hline $\begin{array}{l}36 \text { - Shear is the force that occurs when the skin adheres to a surface and the } \\
\text { body slides in the opposite direction. }(T)\end{array}$ & $27(77.1)$ & $15(100.0)$ & $42(84.0)$ \\
\hline 37 - Friction can occur when moving the person in bed $(T)$ & $31(88.6)$ & $14(93.3)$ & $45(90.0)$ \\
\hline $\begin{array}{l}39 \text { - For people who have incontinence, skin cleansing should take place at the } \\
\text { time they get dirty and at routine breaks. (T) }\end{array}$ & $35(100.0)$ & $14(93.3)$ & $49(98.0)$ \\
\hline 40 - Educational programs can reduce the incidence of PI (T) & $35(100.0)$ & $15(100.0)$ & $50(100.0)$ \\
\hline 41 - Hospitalized patients need to be assessed for risk for PI only once (F) & $34(97.1)$ & $15(100.0)$ & $49(98.0)$ \\
\hline
\end{tabular}

$\mathrm{PI}=$ Pressure Injury; $\mathrm{T}=$ true; $\mathrm{F}=$ false; $\mathrm{N}=$ frequency.

Regarding the comparison in the performance of respondents, the Mann-Whitney statistical test and the $t$ test for independent samples were performed for this purpose. These data are presented in Table 3. 
Table 3. Comparison of correct answers between nurses and nursing technicians, according to the dimensions and totality of the instrument. Dourados (MS), Brasil - 2017.

\begin{tabular}{lccc}
\hline & Instrument Dimension & \multicolumn{2}{c}{ Average score } \\
\cline { 2 - 4 } & Nurses & $\begin{array}{c}\text { Nursing } \\
\text { technicians }\end{array}$ & p \\
\hline Pressure injury assessment and classification & 33.32 & 21.67 & $0.06^{*}$ \\
\hline Pressure Injury Prevention & 30.69 & 19.88 & $0.01^{*}$ \\
\hline All questions & 36.83 & 34.22 & $0.01^{* *}$ \\
\hline
\end{tabular}

* Mann-Whitney Test; ** T test for independent samples.

Nurses had higher scores in relation to the assessment and classification dimensions. ( $U=128,500, z=-2,743$, $\mathrm{p}=0,006)$ and prevention $(U=108,000, \mathrm{z}=-2,529, \mathrm{p}=0,011)$, as well as presented statistically higher scores (Average $=36,8$; $\mathrm{DP}=1,586)$ compared to the technicians (Average $=34,22 ; \mathrm{DP}=3,200)(t(42)=2,694, \mathrm{p}=0,10)$, showing that nurses have a higher level of knowledge than technicians.

When verifying whether the levels of knowledge could be influenced by the factors of working time, the existence of previous training on PI and IAD and the position held, the model described below in Table 4 was obtained.

Table 04. Regression model with predictor variables of adequate knowledge. Dourados (MS), Brasil - 2017.

\begin{tabular}{|c|c|c|c|c|c|c|}
\hline \multirow{2}{*}{ Predictor variables } & \multirow{2}{*}{ Wald } & \multirow{2}{*}{ df } & \multirow{2}{*}{ Sig } & \multirow{2}{*}{$\operatorname{Exp}(B)$} & \multicolumn{2}{|c|}{$95 \%$ C.I. for $\operatorname{Exp}(\mathrm{B})$} \\
\hline & & & & & Minimum & Maximum \\
\hline Working time & 0.150 & 1 & 0.040 & 1.612 & 1.143 & 18.117 \\
\hline Prior PI training & 0.203 & 1 & 0.203 & 1.831 & 0.132 & 25.490 \\
\hline Prior IAD training & 2.126 & 1 & 0.145 & 4.041 & 0.618 & 28.420 \\
\hline Position & 0.126 & 1 & 0.723 & 0.699 & 0.907 & 5.057 \\
\hline Constant & 1.787 & 1 & 0.181 & 0.085 & & \\
\hline
\end{tabular}

$\mathrm{PI}=$ Pressure Injury; IAD = Incontinence Associated Dermatitis.

The model was not statistically significant $\left[^{2}(4)=, 712 \mathrm{p}=0,607\right.$; Nagelkerke $\left.R^{2}=0,095\right]$, in which only working time greater than 5 years was significant for adequate knowledge ( $\operatorname{Exp}(b)$ 1,612 [95\% IC: 1,143-18,117]), demonstrating that the chance of those with more than 5 years of experience presenting an adequate level of knowledge is 1.61 times greater than the chance of those with less than 5 years of experience presenting an adequate level of knowledge.

\section{DISCUSSION}

Considering the overall results of this study, there were significantly higher averages of correct answers among nurses, both for the PI prevention category and for the PI assessment and classification category.

Less satisfactory results were obtained in similar studies with the application of the same knowledge test. In a research carried out with the nursing staff of the Intensive Care Unit, there was a lower total average of correct answers among nurses (51.4\%) than among nursing technicians and assistants $(63,4 \%)^{9}$.

A similar study carried out in Brazil, with the same instrument, found that only 2 nurses (5.2\%) answered $90 \%$ or more of the questions correctly. Most nurses got between $70 \%$ and $89 \%$ of the instrument right ${ }^{15}$.

It is known that it is the nurse's responsibility to privately assess the patients' injuries and the risk of developing wounds, as well as this professional's responsibility to prescribe measures for the prevention, treatment and management of skin lesions, through institutional protocols. Thus, it is expected that nurses have clinical reasoning and adopt assertive behaviors regarding skin lesions and their prevention ${ }^{16}$. 
Regarding PI prevention measures, there were scores below $90 \%$ for both nurses and nursing technicians. This finding is in line with other Brazilian studies, in which knowledge considered inadequate regarding the prevention of PI was identified. This data is worrisome, since this is a preventable injury in most cases, and can be prevented with the implementation of adequate care, based on scientific evidence, which emphasizes the importance of implementing permanent education about this condition ${ }^{8,16,17}$.

In Turkey, researchers used the same Pieper knowledge test to assess nurses' knowledge about PI. Only 8 participants (2.6\%) scored above $80 \%$ and none of the items were answered correctly by all professionals. The investigation highlights that the scores were statistically higher among nurses who read articles, participate in courses related to the topic, care for patients at risk of developing or who have $\mathrm{PI}^{18}$.

In the present study, it was found that the participants had a high rate of correct answers, in both professional groups, in 25 questions (61.0\%). Comparatively, another Brazilian study carried out only with nurses, with the same instrument, showed that only 20 items were answered with a rate of correct answers above the desirable ${ }^{15}$.

A success rate of less than $50 \%$ was found in both professional categories participating in this study in 5 questions (12.2\%). These questions refer to the thickness of the stage $2 \mathrm{PI}$, the use of water gloves for pressure relief, the use of devices with a central orifice to prevent PI, the appropriate degree of elevation of the head of the bed and the frequency of repositioning the patient while sitting in a wheelchair. Other researches identified a low rate of correct answers in the item referring to the use of pillows with central holes to prevent $\mathrm{PI}^{9,15}$.

In some questions in this study, success rates were identified well below the expected in both professional categories. One of these items is related to the application of massage in areas of bony prominences. In similar studies, it was found a rate of correct answers well below the adequate of the participants in the same item ${ }^{9,10}$.

It is known that two decades ago, in the United States of America, a guideline was published that contraindicated the use of water gloves, saline bags and/or pillows with central holes for the prevention of PI. In this document, it was emphasized that massage in bone prominences should not be performed due to the risk of this procedure worsening local congestion, thus increasing the risk of developing an PI. These guidelines are disclosed in more recent documents, including those translated into Portuguese ${ }^{8}$.

In this context, the important role of continuing education within health institutions as an agent of changes in care practices is highlighted. Continuing education is carried out in the service and for the service, that is, it is aimed at answering the servants' doubts regarding the pathologies found in their daily work in the field of health. This education should be seen as a priority within institutions, with the aim of promoting improvements in the care provided to the client ${ }^{19-22}$.

In Brazil, measures related to prevention and treatment protocols with regard to educational activities are recent and have started to be instituted due to institutional accreditations for quality and safety of the patient ${ }^{2,9}$.

The present research has some limitations, among them is the small sample size. In addition, the multidisciplinary team was not included and the degree of knowledge of respondents was not compared before and after carrying out an educational intervention activity. Due to the period of data collection, another limitation is related to the instrument used, since in Brazil there is already a more recent and validated instrument for the same purpose ${ }^{4}$. It is recommended to carry out similar, multicenter studies, in order to investigate the national scenario on the knowledge of nursing professionals about the prevention, evaluation and classification of PI.

\section{CONCLUSION}

In this study, it was possible to identify knowledge gaps among 50 nursing professionals from a medical clinic unit of a university hospital, considering that the average of correct answers regarding the 41 questions was less than $90 \%$.

In order to improve knowledge on this subject, health care institutions must implement permanent education actions about this problem, considering the costs they entail and their complications. These educational processes must be based on dialogue to encourage the exchange of experiences and increase the feeling of belonging to those involved. The use of 
diversified educational strategies, such as conversation circles, printed materials, videos, among others, can be used with the aim of favoring the participants' learning.

\section{AUTHORS' CONTRIBUTION}

Conceptualization: Sokem JAS, Bergamaschi FPR and Watanabe EAMT; Methodology: Sokem JAS, Bergamaschi FPR, Watanabe EAMT, Ferreira AM, Siqueira LDC and Coelho MMF; Research: Sokem JAS, Bergamaschi FPR and Watanabe EAMT; Writing - First version: Sokem JAS, Bergamaschi FPR, Watanabe EAMT, Ferreira AM, Siqueira LDC and Coelho MMF; Writing - Reviewing \& Editing: Sokem JAS, Bergamaschi FPR, Watanabe EAMT, Ferreira AM, Siqueira LDC and Coelho MMF; Resources: Sokem JAS, Bergamaschi FPR and Watanabe EAMT; Supervision: Bergamaschi FPR and Watanabe EAMT.

\section{DATA STATEMENT AVAILABILITY}

All data were generated or analyzed in this study.

\section{REFERENCES}

1. Sassaki RL, Cucolo DF, Perroca MG. Interruptions and nursing workload during medication administration process. Rev Bras Enferm. 2019;72(4):1001-6. http://doi.org/10.1590/0034-7167-2018-0680

2. Agência Nacional de Vigilância Sanitária (BR). Nota técnica GVIMS/GGTES n 03/2017: Práticas seguras para prevenção de Lesão por Pressão em serviços de saúde. Brasília (DF); 2017 [acesso em 30 jul 2021]. Available at: https://www.gov.br/anvisa/ pt-br/centraisdeconteudo/publicacoes/servicosdesaude/notas-tecnicas/nota-tecnica-gvims-ggtes-no-03-2017.pdf

3. National Pressure Ulcer Advisory Panel. National Pressure Ulcer Advisory Panel Responds to Editorial. Adv Skin Wound Care. 2016;29(12):535. https://doi.org/10.1097/01.ASW.0000508227.61503.f9

4. Rabeh SAN, Palfreyman S, Souza CBL, Bernardes RM, Caliri MHL. Cultural adaptation of the Pieper-Zulkowski Pressure Ulcer Knowledge Test for use in Brazil. Rev Bras Enferm. 2018;71(4):2092-100. https://doi.org/10.1590/0034-7167-2017-0029

5. Barbosa JM, Salomé GM. Occurrence of pressure injury in patients hospitalized in a school hospital. ESTIMA, Braz.J. Enterostomal Ther. 2018;16:e2718. https://doi.org/10.30886/estima.v16.523

6. Kayser SA, VanGilder CA, Ayello EA, Lachenbruch C. Prevalence and Analysis of Medical Device-Related Pressure Injuries: Results from the International Pressure Ulcer Prevalence Survey. Adv Skin Wound Care. 2018;31(6):276-85. https://doi.org/10.1097/01. ASW.0000532475.11971.aa

7. Rabeh SAN, Gonçalves MBB, Caliri MHL, Nogueira PC, Miyazaki MY. Terapia tópica para heridas crónicas: contribuciones de un módulo de enseñanza a distancia para el conocimiento de estudiantes de enfermería. Enfermería Global. 2017;16(1):69-101. https://doi.org/10.6018/eglobal.16.1.237361

8. National Pressure Ulcer Advisory Panel; European Pressure Ulcer Advisory Panel; Pan Pacific Pressure Injury Alliance. Prevention and Treatment of Pressure Ulcers: Quick Reference Guide. Emily Haesler (Ed.). Cambridge Media: Osborne Park (Aus); 2019. Available at: https://www.epuap.org/download/11182/

9. Galvão NS, Serique MAB, Santos VLCG, Nogueira PC. Knowledge of the nursing team on pressure ulcer prevention. Rev Bras Enferm. 2017;70(2):294-300. https://doi.org/10.1590/0034-7167-2016-0063

10. De Meyer D, Verhaeghe S, Van Hecke A, Beeckman D. Knowledge of nurses and nursing assistants about pressure ulcer prevention: A survey in 16 Belgian hospitals using the PUKAT 2.0 tool. J Tissue Viability. 2019;28(2):59-69. https://doi. org/10.1016/j.jtv.2019.03.002

11. Charalambous C, Koulouri A, Roupa Z, Vasilopoulos A, Kyriakou M, Vasiliou M. Knowledge and attitudes of nurses in a major public hospital in Cyprus towards pressure ulcer prevention. J Tissue Viability. 2019;28(1):40-45. https://doi.org/10.1016/j. jtv.2018.10.005

12. Damme NV, Hecke AV, Himpens A, Verhaeghe S, Beeckman D. Design and psychometric testing of the attitude towards the prevention of incontinence-associated dermatitis instrument (APrIAD). Int Wound J. 2019;16(2):492-502. https://doi. org/10.1111/iwj.13062 
13. Pieper B, Mott M. Nurses' knowledge of pressure ulcer prevention, stating, and description. Adv Wound Care. 1995 [acesso em 05 ago 2021];8(3):34-48. Available at: http://europepmc.org/abstract/med/7795877

14. Fernandes LM, Caliri MHL, Haas VJ. The effect of educative interventions on the pressure ulcer prevention knowledge of nursing professionals. Acta Paul Enferm. 2008 [acesso em 21 jul 2021];21(2):305-11. Available at: http://www2.unifesp.br/acta/ $\mathrm{pdf} / \mathrm{v} 21 / \mathrm{n} 2 / \mathrm{v} 21 \mathrm{n} 2 \mathrm{a} 12 . \mathrm{pdf}$

15. Sousa RC, Faustino AM. Conhecimento de enfermeiros sobre prevenção e cuidados de lesão por pressão. Fundam Care Online. 2019;11(4):992-7. http://doi.org/10.9789/2175-5361.2019.v11i4.992-997

16. Albuquerque AM, Vasconcelos JMB, Souza APMA, Chaves TRCL, Costa IKF, Soares MJGO. Knowledge test on pressure injury. Rev enferm UFPE on line. 2018;12(6):1738-50. https://doi.org/10.5205/1981-8963-v12i6a234578p1738-1750-2018

17. Portugal LBA, Chirstovam BP, Mendonça RP. The nurses' knowledge about pressure injury care. Revista Enfermagem Atual. 2018;84(22):59-68. http://.doi.org/10.31011/1519-339X.2018a18n84.5

18. Gul A, Andsoy II, Ozkaya B, Zeydan A. A Descriptive, Cross-sectional Survey of Turkish Nurses' Knowledge of Pressure Ulcer Risk, Prevention, and Staging. Ostomy Wound Manage. 2017 [acesso em 04 ago 2021];63(6):40-46. Available at: https://www.owm.com/article/descriptive-cross-sectional-survey-turkish-nurses-knowledge-pressure-ulcer-risk-prevention

19. Ceccim RB. Emergência de um "campo de ação estratégica": ordenamento da formação e educação permanente em saúde. SANARE. 2019 [acesso em 07 set 2021];18(01):68-80. Available at: https://sanare.emnuvens.com.br/sanare/article/ download/1307/688

20. Lavich CRP, Terra MG, Mello AL, Raddatz M, Arnemann CT. Ações de educação permanente dos enfermeiros facilitadores de um núcleo de educação em enfermagem. Rev Gaúcha Enferm. 2017;38(1):e62261. http://doi.org/10.1590/19831447.2017.01.62261

21. Flores GE, Oliveira DLL, Zocche DAA. Permanent education in the hospital context: the experience that brings new meaning to nursing care. Trab. Educ. Saúde. 2016;14( 2):487-504. http://doi.org/10.1590/1981-7746-sip00118

22. Inagaki ADM, Souza IES, Araujo ACL, Abud ACF, Cardoso NP, Ribeiro CJN. Conhecimento de médicos e enfermeiros atuantes no pré-natal sobre toxoplasmose. Cogitare enferm. 2021;26:e70416. http://doi.org/10.5380/ce.v26i0.70416 